\title{
Ectoparasitic flies (Diptera: Streblidae) on bats (Mammalia: Chiroptera) from a Private Natural Heritage Reserve in southeastern Brazil
}

\author{
Luis Fernando Menezes Júnior ${ }^{1,2,3,4}$; Ana Carolina Duarte Pinto Menezes ${ }^{1,3,5}$; Daniel Medina Corrêa Santos ${ }^{2,6}$ \& Adriano Lúcio Peracchi ${ }^{17}$ \\ ${ }^{1}$ Universidade Federal Rural do Rio de Janeiro (UFRRJ), Instituto de Ciências Biológicas e da Saúde (ICBS), \\ Departamento de Biologia Animal, Laboratório de Mastozoologia. Seropédica, RJ, Brasil. \\ ${ }^{2}$ Centro Universitário São José, Curso de Ciências Biológicas (Professor Auxiliar). Rio de Janeiro, RJ, Brasil. \\ 3 Universidade Federal Rural do Rio de Janeiro (UFRRJ), Decanato de Pesquisa e Pós-Graduação, \\ Programa de Pós-Graduação em Biologia Animal. Seropédica, RJ, Brasil. \\ 4 ORCID: http://orcid.org/0000-0001-7407-8829. E-mail: Ifmbio@ig.com.br (corresponding author) \\ ${ }^{5}$ ORCID: http://orcid.org/0000-0001-9489-5922. E-mail: anabiocarol@gmail.com \\ ${ }^{6}$ ORCID: http://orcid.org/0000-0002-0897-9693. E-mail: danielmcs@gmail.com \\ 7 ORCID: http://orcid.org/0000-0002-2181-5095. E-mail: alperacchi@yahoo.com
}

\begin{abstract}
Due to the small number of records of Streblidae on bats, despite extensive study on these mammals in the state of Rio de Janeiro, a survey was carried out in an area of the Atlantic Forest. The present study was carried out at Bom Retiro Farm Natural Heritage Private Reserve. We captured 401 bats of 17 species, 13 genera, and four families; bat flies infested 221 bats of only four species. Carollia perspicillata (Linnaeus, 1758) has the highest fly diversity, with seven fly species: Trichobius joblingi (Wenzel, 1966) $(n=23)$, Megistopoda proxima (Séguy, 1926) $(n=15)$, Strebla guajiro (García \& Casal, 1965) ( $n=15)$, Aspidoptera falcata (Wenzel, 1976) $(n=6)$ Paratrichobius longicrus (Miranda Ribeiro, 1907) $(n=8)$, Paraeuctenodes similis (Wenzel 1976) ( $n=3)$, and Trichobius anducei (Guerrero, 1998) $(n=1)$. Two species infested Platyrrhinus lineatus (É. Geoffroy, 1810): Aspidoptera falcata $(n=1)$ and Anastrebla caudiferae (Wenzel, 1996) $(n=1)$. Paradyschiria parvula (Falcoz, 1931) $(n=11)$ infested Noctilio leporinus (Linnaeus, 1758) and M. proxima $(n=12)$ and Trichobius uniformis (Curran, 1935) $(n=1)$ infested Sturnira lilium (É. Geoffroy, 1842). Sturnira lilium has the highest infestation rate, with ten out of 46 captured individuals parasitized, followed by Carollia perspicillata, with 33 out of 164 captured parasitized, and by $P$. lineatus with only two parasitized individuals out of ten. Among 97 streblid flies captured, M. proxima was the most abundant (27.83\%), followed by T. joblingi (23.71\%), and S. guajiro (15.46\%). All remaining bat fly species represented 33\%. Paradichyria parvula has the first record for Rio de Janeiro State.
\end{abstract}

Key-Words. Flying mammals; Parasitism; Megistopoda proxima; Atlantic Forest.

\section{INTRODUCTION}

Bats are the group of mammals with the second highest species diversity in the Neotropics (Findley, 1993; Nowak, 1994; Voss \& Emmons, 1996; Burgin et al., 2018), only behind rodents. It has 1.386 species world wide (Burgin et al., 2018) and 180 recorded in Brazil (Reis et al., 2017), with seven species included on Brazilian Fauna Red List (ICMBIo/MMA, 2018). Bats maintain parasitic relationships, such as endoparasitism and ectoparasitism. In endoparasitism, the relationships occur with protozoa, helminths, flatworms, and nematodes (Santos \& Gibson, 2015). In the case of ectoparasitism, somearthropods use bats as a means of transport and feed on their hair follicles (Kunz, 1982). Despite the importance of investigating the ectoparasitic insect community, infestation patterns, and the factors that regulate this infestation, these topics are still poorly studied (Rui \& Graciolli, 2005).

The distribution of ectoparasites in bats seems to follow a certain proportionality. The abundance of ectoparasites could differ among hosts in the same population according to different age, sex, and reproductive categories (Marshall, 1982). Cases of ectoparasite over population in bats are rare, as they would result in significant damage to the host, comprising from minor problems to severe injuries, such as blood loss, malnutrition, and skin and fur damage (Kunz, 1982). Only two families of hematophagous dipterans, Streblidae and Nycteribiidae, are known to parasitize bats (Silva \& Ortêncio-Filho, 2011). Together with Glossinidae 
and Hippoboscidae, these families form the superfamily Hippoboscoid within the Calyptrate, infraorder Schizophora, suborder Brachycera (Petersen et al., 2007). The relationships between the families in the superfamily are still in debate, altought two clades have been accepted: Nycteribiidae and Streblidae, and Glossinidae and Hippoboscidae (Petersen et al., 2007).

In Brazil, there are few studies on bat ectoparasites (Komeno \& Linhares, 1999; Bertola et al., 2005) as well as in the state of Rio de Janeiro State (Almeida et al., 2010; França et al., 2013). So, it is possible and expected that new records of the relationship between bat and ectoparasites will be found in areas with few studies. Thus, the present study aims to fill in the knowledge gapabout ectoparasites found on bats captured at Bom Retiro Farm Private Natural Heritage Reserve, inserted in an Atlantic Forest fragment. We want to contribute to the knowledge of the ectofauna streblidae of the state of Rio de Janeiro, as the first record of the ectoparasite Paradichyria parvula (Falcoz, 1931) for the state.

\section{MATERIAL AND METHODS}

This study was carried out at Bom Retiro Farm Private Natural Heritage Reserve (RPPN), here after Bom Retiro Farm $\left(22^{\circ} 27^{\prime} \mathrm{S}, 42^{\circ} 18^{\prime} \mathrm{W}\right)$, wich is located at approximately
$140 \mathrm{~km}$ from the city of Rio de Janeiro, southeastern Brazil. It comprises the municipalcities of Casimiro de Abreu and Silva Jardim, with an area of 494.3 ha (Fig. 1), mostly covered by typical Atlantic Forest vegetation, which remains under the influence of the Tropical Atlantic Mass originated from the Tropical Atlantic Antictone for most of the year. The studied area is with in São João River Basin, in an intertropical zone (low latitudes), with intense solar radiation, under high influence of the Atlantic Ocean, with average annual temperatures of $18^{\circ}$ to $24^{\circ}$ (Cunha, 1995), and a predominantly humid tropical climate (Takizawa, 1995). Private Natural Heritage Reserves (RPPN) are private areas chosen to be protected byan initiative of owners, upon recognition by the Government (Federal Decree \#1922/1996). They are relevant due to their biodiversity, landscape aspect and/or environmental characteristics that justify recovery actions. The regulation of RPPNs began in 1990, by the request of some landowners who wanted to turn part of their real estate into private reserves that allowed touristic and research activities (IBAMA, 2005).

Nineteen field expeditions were carried out between January 2012 and May 2016. Bats were captured using mist nets measuring $9 \mathrm{~m} \times 2,5 \mathrm{~m}$. In each campaign, five networks that were opened for 12 hours a night were used, with an capture effort of $25.650 \mathrm{k} . \mathrm{m}^{2}$, following Straube \& Bianconi (2002). The bats which were

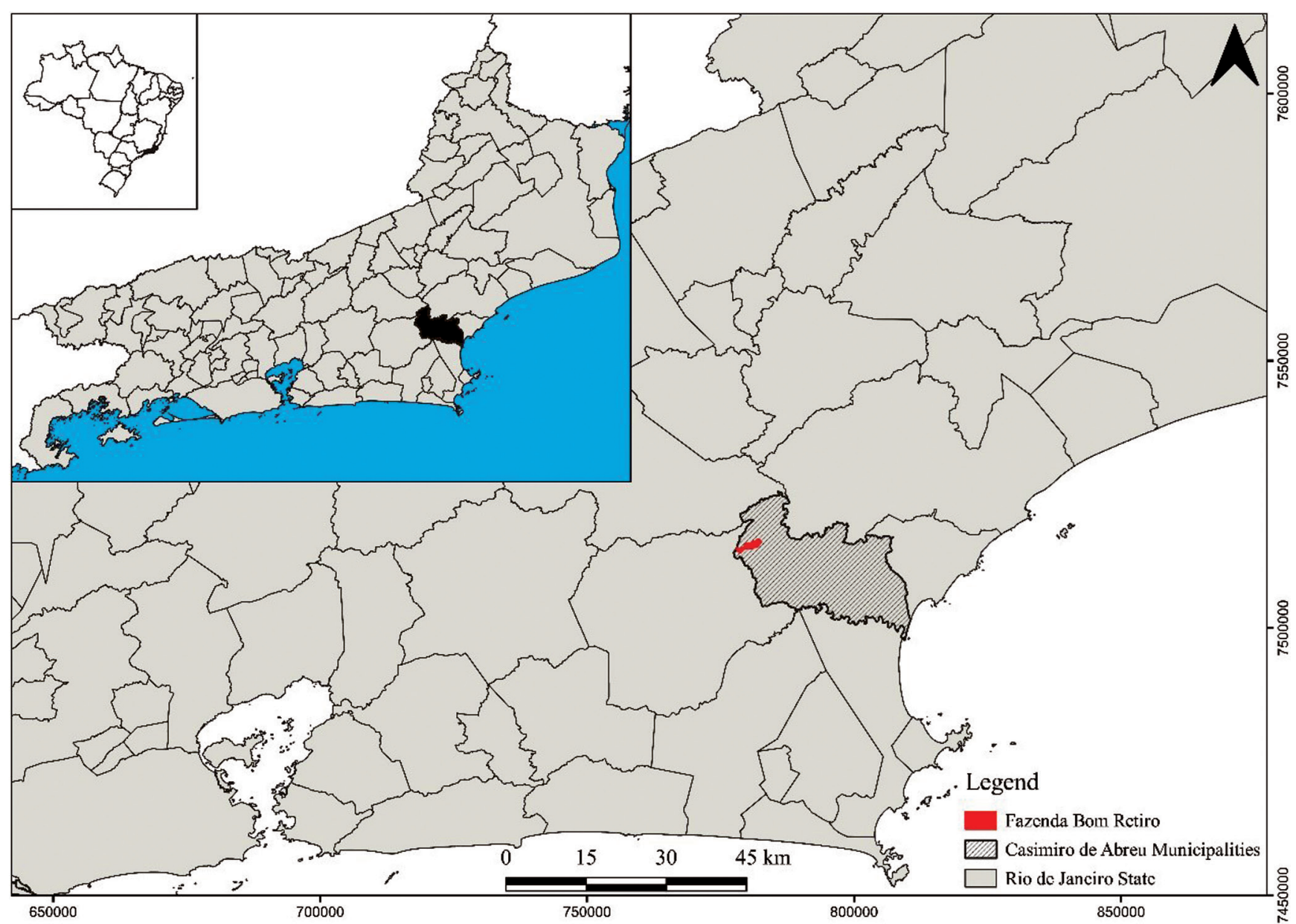

Figure 1. Location of the Bom Retiro Farm Private Natural Heritage Reserve $\left(22^{\circ} 27^{\prime} S, 42^{\circ} 18^{\prime} \mathrm{W}\right)$, Silva Jardim, Rio de Janeiro, southeastern Brazil. 
captured were put in individual cloth bags, previously identified in the field, using the identification keys by Emmons \& Feer (1997) and descriptions provided by Simmons \& Voss (1998), Dias et al., (2002), and Dias \& Peracchi (2008). The first specimen of each species captured and the specimens that raised doubts about identification were sacrificed and preserved in 70\% alcohol. Voucher specimens were deposited in the Adriano Lúcio Peracchi Collection (ALP) of the Mastozoology Laboratory, Institute of Biology, Federal Rural University of Rio de Janeiro (UFRRJ). We declare that all actions performed with the animals have followed and respected the international rules of animals well being, through all parameters required from Animal Ethics Committee (AEC).

The bats analyzed were marked using the capture-mark-recapture method with numbered plastic collars, following Esbérard \& Daemon (1999), and then released.

Flies on the body surface of bats were collected with tweezers. Captured ectoparasites were fixed in 70\% alcohol and stored in Eppendorf tubes with a label identifying the bat species on which the fly was collected, as well as the site and date of collection. Dr. Gustavo Graciolli, professor at the Biology Institute, Federal University of Mato Grosso do Sul, identified streblid flies.

Associations between streblid flies and bats were analyzed by counting the number of bats captured and the number of infested bats. We also calculated the average prevalence by counting the number of ectoparasites on each bat species in relation to the number of ectoparasites collected and calculated the prevalence of ectoparasites (Margolis et al., 1982). To test for differences in the number of ectoparasites in different bat species, regardless of sex, parasite or weight, the Mann-Whitney test was applied. Species with a few number of individuals were not included in the stastical test. We used the cluster analysis to compare the present study with five other studies carried out in different locations: Distrito Federal (Graciolli \& Coelho, 2001), Maranhão (Santos et al., 2009), São Paulo (Bertola et al., 2005), Minas Gerais (Komeno \& Linhares, 1999), Paraná (Graciolli \& Bianconi, 2007) and Rio de Janeiro II (França et al., 2013).

\section{RESULTS}

\section{Richness and relative abundance of species of flies and bats}

401 bats of 17 species, 13 genera, and four families were captured: family Phyllostomidae: Carollia perspicillata (Linnaeus, 1758) $\mathrm{n}=164$, Desmodus rotundus (É. Geoffroy, 1810) $n=64$, Sturnira lilium (É. Geoffroy, 1842) $\mathrm{n}=46$, Artibeus lituratus (Olfers, 1818) $\mathrm{n}=28$, Artibeus fimbriatus (Gray, 1838) $n=24$, Artibeus obscurus (Schinz, 1821) n=22, Anoura geoffroyi (Gray, 1838) $n=22$, Glossophaga soricina (Pallas, 1766) $\mathrm{n}=10$, Platyrrhinus lineatus (É. Geoffroy, 1810) $n=10$, Platyrrhinus recifinus (Thomas, 1901) $\mathrm{n}=6$, Diphylla ecaudata (Spix, 1823) $\mathrm{n}=4$, Diaemus youngii (Jentink, 1893) $\mathrm{n}=2$, Dermanura cinerea (Gervais, 1856) $\mathrm{n}=2$, and Phyllostomus hastatus (Pallas, 1767) $\mathrm{n}=2$; family Noctilionidae: Noctilio leporinus (Linnaeus, 1758) $n=1$; family Vespertilionidae: Myotis nigricans (Schinz, 1821) $\mathrm{n}=1$; and family Molossidae: Molossus molossus (Pallas, 1766) $n=1$.

A total of ten streblid species of eight genera was collected: Anastrebla caudiferae (Wenzel, 1996) $\mathrm{n}=1$, Aspidoptera falcata (Wenzel, 1976) $\mathrm{n}=7$, Megistopoda proxima (Séguy, 1926) $\mathrm{n}=27$, Paratrichobius longicrus (Miranda-Ribeiro, 1907) $\mathrm{n}=8$, Paradychiria parvula (Falcoz, 1931) $\mathrm{n}=11$, Paraeuctenodes similis (Wenzel, 1976) $n=3$, Strebla guajiro (García \& Casal, 1965) $n=15$, Trichobius anducei (Guerrero, 1998) $\mathrm{n}=1$, Trichobius joblingi (Wenzel, 1966) $\mathrm{n}=23$, and Trichobius uniformis (Curran, 1935) $\mathrm{n}=1$. Megistopoda proxima was the most abundant species $(27.83 \%)$, followed by T. joblingi $(23.71 \%)$, and S. guajiro (15.46\%). Together, the other species represented $33 \%$ of all collected specimens.

These ten species correspond to 97 specimens: 48 males $(49.49 \%)$ and 49 females $(50.51 \%)$. The male-female ratio was 1:1.02. Sex-ratio was proportional in all fly species captured, with a larger number of females in six of ten species: A. falcata, M. proxima, P. parvula, P. similis, S. guajiro, and T. joblingi. Paratrichobius longicrus showed the same number of males and females. We captured only one male of $A$. caudiferae and T. uniformis, and only one female of $T$. anducei (Table 1).

\section{Association of flies and bats}

Streblids infested four bat species: Carollia perspicillata, Noctilio leporinus, Sturnira lilium, and Platyrrhinus lineatus. We collected 38 females and 33 males on C. perspicillata, seven females and six males on S. lilium, six females and five males on $N$. leporinus, and one female and one male on $P$. lineatus.

The specie with the highest number of streblid species was C. perspicillata, with seven species. Secondly, Platyrrhinus lineatus and S. lilium, both with two species captured on each. Noctilio leporinus was parasitized only by one species. Sturnira lilium showed the highest infestation rate: ten out of 46 captured individuals showed ectoparasitic flies; followed by Carollia perspicillata with 33 out of 164 captured specimens parasitized, and $P$. lineatus with two out of ten individuals parasitized (Table 1). Megistopoda proxima and A. falcata were the only species on two different bat species; the former parasitized C. perspicillata and S. lilium and the latter parasitized C. perspicillata and $P$. lineatus.

The Mann-Whitney test used to compare the number of ectoparasites on C. perspicillata and S. lilium, regardless of sex, parasite or weight was significant $(U=70$, $Z=2.4$, and $p=0.01$ ). Carollia perspicillata was more parasitized than S. lilium. Other species were not included in the analysis due to the small number of individuals captured. According to the cluster analysis, there is a similarity between Rio de Janeiro, São Paulo, Minas Gerais and Paraná (Fig. 2). 
Table 1. List of bats and ectoparasites species found in the present study and their sexual proportion.

\begin{tabular}{|c|c|c|c|c|c|c|}
\hline Bat & $\mathrm{Nm}$ & $\mathrm{Ni}$ & $\mathrm{Pm}$ & Ectoparasite & $\mathrm{Ne}\left(\% / \sigma^{\gamma}\right)$ & $\mathrm{Pe}$ \\
\hline \multirow[t]{7}{*}{ Carollia perspicillata (Linnaeus 1758) } & 164 & 33 & 20.1 & Trichobius anducei Guerreiro 1998 & $1($ (\$) & 0,01 \\
\hline & & & & Trichobius joblingi Wenzel 1966 & $23\left(12+/ 11 \sigma^{7}\right)$ & 0,32 \\
\hline & & & & Strebla guajiro (Garcia \& Casal 1965) & $15\left(8 \% / 7 \sigma^{7}\right)$ & 0,21 \\
\hline & & & & Paraeuctenodes similis Wenzel 1976 & $3\left(2 \% / 1 \sigma^{7}\right)$ & 0,42 \\
\hline & & & & Paratrichobius Iongicrus (Miranda-Ribeiro 1907) & $8\left(4+/ 4 \sigma^{7}\right)$ & 0,11 \\
\hline & & & & Aspidoptera falcata Wenzel 1976 & $6\left(3 \% / 3 \sigma^{7}\right)$ & 0,08 \\
\hline & & & & Megistopoda proxima (Séguy 1926) & $15\left(8 \% / 7 \varnothing^{7}\right)$ & 0,21 \\
\hline \multirow[t]{2}{*}{ Sturnira lilium É. Geoffroy 1842} & 46 & 10 & 21.7 & Megistopoda proxima (Séguy 1926) & $12\left(6 \% / 6 \sigma^{7}\right)$ & 0,92 \\
\hline & & & & 'Trichobius uniformis Curran 1935 & $1(\%)$ & 0,08 \\
\hline Noctilio leporinus (Linnaeus 1758) & 1 & 1 & 100 & aParadychiria parvula Falcoz 1931 & $11\left(69 / 6 \sigma^{7}\right)$ & 1 \\
\hline \multirow[t]{2}{*}{ Platyrhinus lineatus (É. Geoffroy 1810) } & 10 & 2 & 20 & Aspidoptera falcata Wenzel 1976 & $1(\%)$ & 0,5 \\
\hline & & & & Anastrebla caudiferae Wenzel 1996 & $1\left(0^{r}\right)$ & 0,5 \\
\hline Total & 221 & 46 & & & $97\left(52 \% / 45 \sigma^{7}\right)$ & \\
\hline
\end{tabular}

$\mathrm{Nm}=$ number of bats captured; $\mathrm{Ni}=$ number of bats infested; $\mathrm{Pm}=$ prevalence of ectoparasites on bat species; $\mathrm{Ne}=$ number of ectoparasites collected, $\mathrm{Pe}=$ Prevalence of ectoparasites,

$\mathrm{a}=$ new record for Rio de Janeiro, ${ }^{\mathrm{b}}=$ second record for Rio de Janeiro.

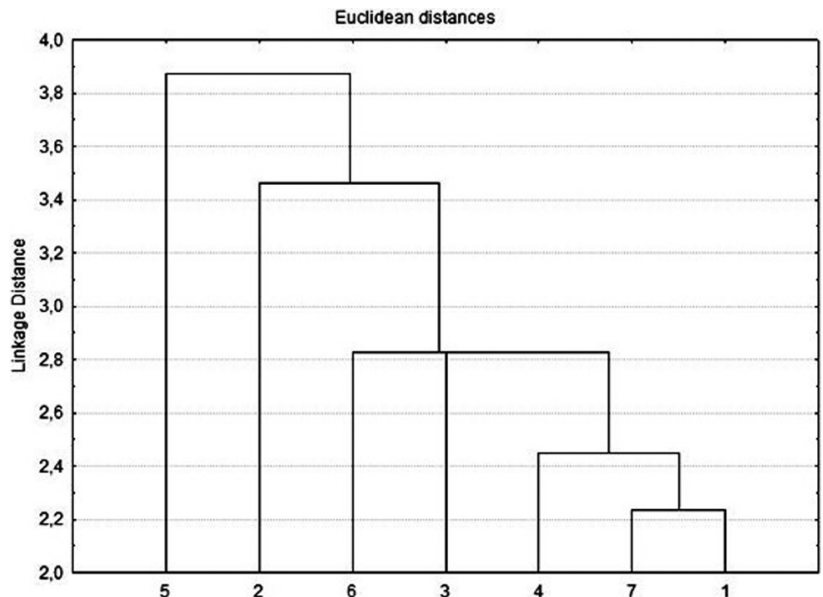

Figure 2. Cluster analysis comparing studies carried out in five other Brazilian states: (1) Graciolli \& Bianconi (2007) in Paraná, (2) Santos et al. (2009) in Maranhão, (3) Bertola et al. (2005) in São Paulo, (4) Komeno \& Linhares (1999) in Minas Gerais, (5) Graciolli \& Coelho (2001) in Distrito Federal, (6) the present study in Rio de Janeiro and (7) França et al. (2013) in Rio de Janeiro II.

\section{DISCUSSION}

\section{Fly species richness and relative abundance}

The present study represents about $10 \%$ of the Streblidae species that occur in Brazil (Eriksson et al., 2011; Graciolli \& Azevedo, 2011; Graciolli \& Dick, 2012).

The Streblidae richness at Bom Retiro Farm did not differ from the average observed in other studies (Table 2). When compared, our results regarding the number of bats analyzed, both the number of host species (4) and the number of fly species (10) were lower than recorded in other studies (e.g., Bertola et al., 2005, carried out in São Paulo). When comparing the present study with the other six carried out in different locations (Distrito Federal, Maranhão, São Paulo, Minas Gerais, Paraná, and Rio de Janeiro II), using a cluster tree, an important similarity in streblid composition related to the distance between research islands was observed (Fig. 2). There is a similarity
Table 2. Published studies in other states with the family Streblidae.

\begin{tabular}{lcccc}
\hline \multicolumn{1}{c}{ Authors } & State & Number of taxa & $\begin{array}{c}\text { Number of } \\
\text { ectoparasites }\end{array}$ & $\begin{array}{c}\text { Number } \\
\text { of host } \\
\text { species }\end{array}$ \\
\hline Graciolli \& Bianconi (2007) & Paraná & 7 spp and 6 genera & 119 & 4 \\
Komeno \& Linhares (1999) & Minas Gerais & 11 spp and 6 genera & 158 & 12 \\
Santos et al. (2009) & Maranhão & 15 spp and 8 genera & 201 & 9 \\
Bertola et al. (2005) & São Paulo & 17 spp and 11 genera & 443 & 22 \\
Graciolli \& Coelho (2001) & Distrito Federal & 13 spp and 4 genera & 102 & 8 \\
França et al. (2013) & Rio de Janeiro & 9 spp and 6 genera & 126 & 7 \\
Present study & Rio de Janeiro & 10 spp and 8 genera & 97 & 4 \\
\hline
\end{tabular}

between the results obtained and the distance, as closer states, such as São Paulo, Minas Gerais, and Paraná, have more species in common than Distrito Federal and Maranhão, which are far from each other. The similarity in the faunal composition of streblids in four of six studies (Rio de Janeiro, São Paulo, Minas Gerais and Paraná), may be related to the fact that these works also had a large amount of capture of C. perspicillata; more over, these have also been carried out in the same ecossystem, the Atlantic Forest, with the exception of Minas Gerais, which was in the Cerrado.

The high species richness of the family Streblidae found in Maranhão can be related to the higher abundance and distribution of this group in equatorial regions (Guerrero, 1993, 1994, 1995a, b; Santos et al., 2009).

Regarding the male-female ratio, the present study showed a slight dominance of females, as reported only by Santos et al. (2009). Usually, the number of male is higher, probably because they move more than females (Wenzel, 1976), which are more restricted to the roost for breeding purposes.

The present study records for the first time Paradyschiria parvula for the state of Rio de Janeiro, previously found only in the states of Pará and Rondônia in the North, Maranhão in the Northeast, Mato Grosso and Mato Grosso do Sul in the Mid west, and Paraná in the South (Graciolli, 2020). All P. parvula specimens (5 males and 6 females) were captured parasitizing a female from Noctilio leporinus. In addition to this, the second record 
of Trichobius uniformes for the state of Rio de Janeiro was made in present study, with a female parasitizing Sturnira lilium being, which the first record was made by Lourenço et al. (2020).

\section{Association of flies and bats}

A total of 45 out of 221 bats had ectoparasites, which represents an infestation rate of $20.4 \%$. Bats of the family Phyllostomidae were the most parasitized by ectoparasites, and C. perspicillata obtained a higher number of species than that observed in studies carried out in Minas Gerais (Komeno \& Linhares, 1999), São Paulo (Graciolli et al., 2006) and Rio de Janeiro II (França et al., 2013). Carollia perspicillata had seven species, a number higher than those found in the study of Bertola et al. (2005; 5 species), Santos et al. (2009; 4 species), and França et al. (2013; 4 species). Simmons \& Voss (1998) and Carvalho et al. (2013) pointed out that the height of mist nets between 2.5 and 3 meter sallow shigh capture of phyllostomines, in particular frugivores and nectarivores, as they prefer to fly at the understory level. The high number of C. perspicillata may be related to the predominance of plants of the family Piperacea at Bom Retiro Farm, as species of this family comprises the most visited plants by C. perspicillata during feeding (Pereira et al., 2018; Muller $\&$ Reis, 1992). Among the ectoparasites found on C. perspicillata, T. joblingi was also observed in Minas Gerais (Komeno \& Linhares, 1999), Maranhão (Santos et al., 2009), São Paulo (Bertola et al., 2005), Distrito Federal (Graciolli \& Coelho, 2001), and Rio de Janeiro II (França et al., 2013); in all of these studies, this species was the most captured on C. perspicillata. Strebla guajiro was also observed in those studies, except for Distrito Federal (Graciolli \& Coelho, 2001).

In the present study, we captured two ectoparasites of the Streblidae family on $P$. lineatus ( $A$. falcata and $A$. caudiferae), but none of the other studies compared here reported the presence of ectoparasites on this bat species. The presence of P. parvula parasitizing N. leporinus corroborates previous findings, as this bat is considered one of the host types of this parasite (Graciolli \& Carvalho, 2001).

The records of parasite-host associations and the occurrence of streblids carried out in the study represent a significant contribution to deepening the knowledge about the distribution of fly species and their relationship with bats. The few existing studies, presented here in this work, show how this group and the relationship of ectoparasitism with bats is neglected. Further more, understanding these ecological relationships can help in the management and conservation processes of these taxonomic groups, especially in environments such as fragments of the Atlantic Forest, a biodiversity hotspot. Our results show the need to expand these studies, not only to other areas but also in the same region of the present study, thus improving the understanding of ectoparasitism relationships between these groups and how the processes of fragmentation and loss of habitat can interfere in this.

\section{ACKNOWLEDGMENTS}

We thank Maycon Contildes, Emerson Martins Pereira and Carlos Alberto Soares Raimundo for their help with fieldwork. Professor Dr. Gustavo Graciolli helped with streblid identification. To teacher Adriano Lúcio Peracchi for the orientation. We also thank Luiz Nelson, owner of Bom Retiro Farm for his friendly welcome to his property. Chico Mendes Institute for Biodiversity Conservation ICMBio (SISBIO) granted us the research permit (34216-4).

\section{AUTHORS' CONTRIBUTIONS}

LFMJ: Conceptualization, Methodology, Software, Data curation, Formal analysis, Writing - original draft, Visualization, Investigation. Writing - review \& editing. ACDPM: Writing - review \& editing. DMCS: Writing - review \& editing. ALP: Supervision, Writing - review \& editing.

\section{REFERENCES}

Almeida, J.; Pereira, S.; Serra-Freire, N. \& Peracchi, A.L. 2010. Diversidade ectoparasitológica em morcegos na Fazenda Marambaia, Rio de Janeiro, Brasil. Chiroptera Neotropical, 16(1 Supl.): 118-121.

Bertola, P.B.; Aires, C.C.; Favorito, S.E.; Graciolli, G.; Amaku, M. \& Pinto-daRocha, R. 2005. Batflies, (Diptera: Streblidae, Nycteribiidae) parasitic on bats (Mammalia: Chiroptera) at Parque Estadual da Cantareira, São Paulo, Brazil: parasitism rates and host-parasite associations. Memórias do Instituto Oswaldo Cruz, Rio de Janeiro, 100(1): 25-32.

Burgin, C.J.; Colella, J.P.; Khan, P.L. \& Upham, N.S. 2018. How many species of mammals are there? Journal of Mammalogy, 99(1): 1-14.

Carvalho, W.D.; Godoy, M.S.M.; Adania, C.H. \& Esbérard, C.E.L. 2013. Assembléia de mamíferos não voadores da Reserva Biológica Serra do Japi, Jundiaí, São Paulo, sudeste do Brasil. Bioscience Journal, 29(5): 1370-1387.

Cunha, S.B. 1995. Impactos das obras de engenharia sobre o ambiente biofísico da Bacia do Rio São João (Rio de Janeiro - Brasil). Rio de Janeiro, Edição do Autor. 415p.

Dias, D. \& Peracchi, A.L. 2008. Quirópteros da Reserva Biológica do Tinguá, Nova Iguaçu, Estado do Rio de Janeiro, Brasil (Mammalia, Chiroptera). Revista Brasileira de Zoologia, 25(2): 333-369. D0I

Dias, D.; Peracchi, A.L. \& Silva, S.S.P. 2002. Quirópteros do Parque Estadual da Pedra Branca, Rio de Janeiro, Brasil (Mammalia, Chiroptera). Revista Brasileira de Zoologia, 19(2): 113-140. DOI

Emmons, L.H. \& Feer, F. 1997. Neotropical rainforest mammals: a field guide. 2.ed. Chicago, The University of Chicago Press. 392 p.

Eriksson, A.; Graciolli, G. \& Fischer, E. 2011. Bat flies on phyllostomid hosts in the Cerrado region: component community, prevalence and intensity of parasitism. Memórias do Instituto Oswaldo Cruz, Rio de Janeiro, 106(3): 274-278. DOI

Esbérard, C.E.L. \& Daemon, C. 1999. Um novo método para marcação de morcegos. Chiroptera Neotropical, 5(1-2): 116-117.

Findley, J.S. 1993. Bats: acommunity perspective. Cambridge University Press, Cambridge, 167p.

França, D.S.; Pereira, S.N.; Maas, A.C.S.; Martins, M.A.; Bolzan, D.P.; Lima, I.P.; Dias, D. \& Peracchi, A.L. 2013. Moscas ectoparasitas (Diptera, Streblidae) de morcegos (Chiroptera, Phyllostomidae) em uma área de 
Mata Atlântica, sudeste do Brasil. Revista Brasileira de Biologia, 73(4): 847-854. DOI

Graciolli, G. 2020. Streblidae in Catálogo Taxonômico da Fauna do Brasil. PNUD. Available: http://fauna.jbri.gov.br/faunadobrasil/6423. Access: 22/05/2020

Graciolli, G. \& Azevedo, A.A. 2011. Ectoparasites of bats (Chiroptera, Furipteridae), with a description of a new species of Synthesiostrebla Townsend (Diptera, Streblidae) from Brazil. Revista Brasileira de Entomologia, 55 (4): 501-504. D01

Graciolli, G. \& Bianconi, G. 2007. Moscas ectoparasitas (Diptera, Streblidae e Nycteribiidae) em morcegos (Mammalia, Chiroptera) em área de floresta com araucária no Estado do Paraná, Sul do Brasil. Revista Brasileira de Zoologia, 24(1): 246-249. DOI

Graciolli, G. \& Carvalho, C.J.B. 2001. Moscas ectoparasitas (Diptera, Hippoboscoidea, Nycteribiidae) de morcegos (Mammalia, Chiroptera) do Estado do Paraná. II. Streblidae. Chave pictórica para gêneros e espécies. Revista Brasileira de Zoologia, Curitiba, 18(3): 907-960. D0I

Graciolli, G. \& Coelho, D.C. 2001. Streblidae (Diptera, Hippoboscoidea) sobre morcegos filostomídeos (Mammalia, Chiroptera) em cavernas do Distrito Federal Brasil. Revista Brasileira de Zoologia, 18(3): 965-970. D0l

Graciolli, G. \& Dick, C.W. 2012. Description of a second species of Joblingia Dybas \& Wenzel, 1947 (Diptera: Streblidae). Systematic Parasitology, 81(3): 187-193.

Graciolli, G.; Passos, F.C.; Pedro, W.A. \& Lim, B.K. 2006. Moscas ectoparasitas (Diptera, Streblidae) de morcegos filostomídeos (Mammalia, Chiroptera) na Estação Ecólogica dos Caetetus, São Paulo, Brasil. Revista Brasileira de Zoologia, 23(1): 298-299. DOI

Guerrero, R. 1993. Catalogo de los Streblidae (Diptera: Pupipara) parasitos de murcielagos (Mammalia: Chiroptera) del Nuevo Mundo. I. Clave para los gêneros y Nycterophilinae. Acta Biologica Venezuelica, 14: 61-75.

Guerrero, R. 1994. Catalogo de los Streblidae (Diptera: Pupipara) parasitos de murcielagos (Mammalia: Chiroptera) del Nuevo Mundo. II. Los grupos: pallidus, caecus, major, uniformis y longipes del gênero Trichobius Gervais, 1844. Acta Biologica Venezuelica, 15(1): 1-18.

Guerrero, R. 1995a. Catalogo de los Streblidae (Diptera: Pupipara) parasitos de murcielagos (Mammalia: Chiroptera) del Nuevo Mundo. III. Los grupos: dugesii, dunni y phyllostomae del gênero Trichobius Gervais, 1844. Acta Biologica Venezuelica, 15(3-4): 1-27.

Guerrero, R. 1995b. Catalogo de los Streblidae (Diptera: Pupipara) parasitos de murcielagos (Mammalia: Chiroptera) del Nuevo Mundo. V. Trichobiinae com alas reducidas 0 ausentes y miscelaneos. Boletín de Entomología Venezolana, 10: 135-160.

Instituto Brasileiro do Meio Ambiente e dos Recursos Naturais Renováveis (IBAMA). 2005. Unidade de Conservação/Reservas Particulares do Patrimônio Nacional. Available: http://www.ibama.gov.br. Access: 10/07/2005.

Instituto Chico Mendes de Conservação da Biodiversidade (ICMBio)/ Ministério do Meio Ambiente (MMA). 2018. Livro Vermelho da Fauna Brasileira Ameaçada de Extinção. Brasília, DF., Instituto Chico Mendes de Conservação da Biodiversidade. v. 1, 495p.

Komeno, C.A. \& Linhares, A.X. 1999. Batflies parasitic on some phyllostomid bats in southern Brazil: parasitism rates and hostparasite relationships. Memórias do Instituto Oswaldo Cruz, 94(2): 151-156.

Kunz, T.H. 1982. Roosting ecology of bats,. In: Kunz, T.H. (Ed.). New York, Plenum Press. p. 1-55.
Lourenço, E.C.; Gomes, L.A.C.;Viana, A.0. \& Famadas, K.M. 2020. Co-occurrence of Ectoparasites (Insecta and Arachnida) on Bats (Chiroptera) in an Atlantic Forest Remnant, Southeastern Brazil. Acta Parasitologica, 65: 750-759.

Margolis, L.; Esch G.W.; Holmes, J.C.; Kuris, A.M. \& Schad, G.A. 1982. The use of ecological terms in parasitology (Report of an ad hoc committee of the American Society of Parasitologists). Journal of Parasitology, 68(1): 131-133.

Marshall, A.G. 1982. Ecology on insects ectoparasitic insects. Ecology of Bats. New York, Plenum. 450p.

Muller, M.F. \& Reis, N.R. dos. 1992. Partição de recursos alimentares entre quatro espécies de morcegos frugívoros (Chiroptera, Phyllostomidae). Revista Brasileira de Zoologia, 9(3-4): 345-355. D01

Nowak, R.M. 1994. Walker's Bats of the World. Baltimore, The Johns Hopkins University Press. 287p.

Pereira, E.M.; Menezes-Jr., L.F.; Menezes, A.C.D.P. \& Santos, D.M.C. 2018. Horário de atividades de três espécies de morcegos da RPPN Fazenda Bom Retiro, Casimiro de Abreu, RJ. Revista Ciência Atual, Rio de Janeiro, 11(1): 2-15. Available: http://www.cnad.edu.br/revista-ciencia-atual/ index.php/cafsj/article/view/236/pdf. Access: 04/07/2019.

Petersen, F.T.; Meier, R.; Kutty, S.N. \& Wiegmann, B.M. 2007. The phylogeny and evolution of host choice in the Hippoboscoidea (Diptera) as reconstructed using four molecular markers. Molecular Phylogenetics and Evolution, 45: 111-122.

Reis, N.R.; Peracchi, A.L.; Batista, C.B.; Lima, I.P. \& Pereira, A.D. 2017. História natural dos morcegos brasileiros, chave de identificação de espécies. Rio de Janeiro,Technical Books Editora. 416p.

Rui, A.M. \& Graciolli, G. 2005. Moscas ectoparasitas (Diptera, Strebliidae) de morcegos (Chiroptera, Phyllostomidae) no sul do Brasil: Associações Hospedeiros - Parasitos e Taxas de Infestação. Revista Brasileira de Zoologia, 22(2): 438-445.

Santos, C.L.C.; Dias, P.A.D.; Rodrigues, F.S.; Lobato, K.S.; Rosa, L.C.; Oliveira, T.G. \& Rebelo, J.M.M. 2009. Moscas ectoparasitas (Diptera: Streblidae) de morcegos (Mammalia: Chiroptera) do Município de São Luiz, MA: Taxas de Infestação e associações parasito-hospedeiro. Neotropical Entomology, 38(5): 595-601. DOI

Santos, C.P. \& Gibson, D.I. 2015. Checklist of the Helminth parasites of South American bats. Zootaxa, 3937(3): 471-499.

Silva, J.R.R. da \& Ortêncio-Filho, H. 2011. Dípteros ectoparasitas (Insecta, Diptera) em morcegos (Chiroptera, Mammalia) na Reserva Biológica das Perobas Paraná, Brasil. Iheringia. Série Zoologia, 101(3): 220-224. D0I

Simmons, N.B.\& Voss, R.S. 1998. The mammals of Paracou, French Guiana: A neotropical lowland rainforest fauna part 1. Bats. Bulletin of the American Museum of Natural History, 237: 1-219.

Straube, F.C \& Bianconi, G.V. 2002. Sobre a grandeza e a unidade utilizada para estimar esforço de captura com utilização de redes-de-neblina. Chiroptera Neotropical, 8(1-2): 150-152.

Takizawa, F.H. 1995. Levantamento pedológico e zoneamento ambiental da Reserva Biológica de Poço das Antas. Piracicaba, Escola Superior de Agricultura Luis de Queiroz/USP. 56p. Monografia de Graduação. Departamento Ciências do Solo.

Voss, R.S. \& Emmons, L.H. 1996. Mammalian diversity in neotropical lowland rainforests: a preliminary assessment. Bulletin of the American Museum Of Natural History, New York, 230: 1-115.

Wenzel, R.L. 1976. The streblid bat flies of Venezuela (Diptera: Streblidae). Brighan Young University Science Bulletin, Biological Series, 20(4): 1-177. 